\title{
Notes on Neotropical Proconiini (Hemiptera: Cicadellidae: Cicadellinae). VII: First detailed description of the female genitalia of a Diestostemma species
}

\author{
Gabriel Mejdalani ${ }^{1,2} \&$ Roberta dos Santos da Silva ${ }^{1}$
}

\author{
${ }^{1}$ Departamento de Entomologia, Museu Nacional, Universidade Federal do Rio de Janeiro. Quinta da Boa Vista, \\ São Cristóvão, 20940-040 Rio de Janeiro, RJ, Brazil. \\ 2 Corresponding author. E-mail: mejdalan@acd.ufrj.br; gmejdalani@uol.com.br
}

\begin{abstract}
Diestostemma Amyot \& Serville, 1843 is a diverse sharpshooter genus with 32 species. A description and illustrations of Diestostemma nasutum Schmidt, 1910 are provided. The species, previously known from Ecuador, is newly recorded from Colombia. Both the male and female genitalia are described for the first time. This is the first detailed description of the female genitalia of a Diestostemma species. Diestostemma nasutum can be distinguished from the other species of the genus by the following features of the aedeagus: shaft with the distal third distinctly curved dorsally; base of basiventral aedeagal process with a lobe directed anteriorly; and basiventral aedeagal process bifurcated on its basal portion. The style of $D$. nasutum, whose apical portion is broad, distinctly curved inward, and with the apex subtruncate, is also quite distinctive. We compared the female genitalia of $D$. nasutum with those of other Proconiini genera. Our results confirm the perception that the female genitalia in this tribe can be a source of useful taxonomic characters.
\end{abstract}

KEY WORDS. Auchenorrhyncha; Diestostemma nasutum; male; Membracoidea; morphology; sharpshooter; taxonomy.

This is the seventh paper of a series on the taxonomy of the Proconiini from the Neotropical region. Previous papers of the series included descriptions of four new species and notes on other species in the tribe (Mejdalani \& Emmrich 1998, Сеотто et al. 2000, Mejdalani 2006, Mejdalani et al. 2006, 2008, 2009). One of the goals of this series is to improve our taxonomical knowledge of species that are poorly described and, thus, are of difficult identification. This is the case of the species treated in the present paper, which was initially mistaken for a new species.

Diestostemma nasutum was described by SCHмIDT (1910) based on material from Ecuador (Coca, province of Orellana; Balzapamba, province of Bolívar). Young (1968), in his revision of the Proconiini, included D. nasutum in the key to species of Diestostemma Amyot \& Serville, 1843. However, he did not provide illustrations of the external parts or of the male genitalia of this species. Thus, the identification of D. nasutum has been difficult, even when the fairly detailed original German description of SснміDт (1910), which has no illustrations, is available. Descriptions and illustrations of the male and female of $D$. nasutum are herein provided. This is the first detailed treatment of the female genitalia of a Diestostemma species. The female genitalia of $D$. nasutum are compared with other Proconiini genera for which these structures have been described in detail.

A male and a female D. nasutum from Colombia (new record), housed in the collection of the Museum für Tierkunde in Dresden (SMTD), were studied. The specimens were identi- fied using the original description of SснмiDT (1910) and photographs of the female lectotype available in the internet site "Sharpshooter Leafhoppers of the World" (WILson et al. 2009).

The morphological terminology herein adopted mostly follows Young (1968), except for the facial areas of the head (Hamilton 1981, Mejdalani 1998) and the female genitalia (Nielson 1965, HILL 1970). Use of the term gonoplac (= third ovipositor valvula) and the names for the processes of the dorsal and ventral sculptured areas of the first ovipositor valvula follow Mejdalani (1998). The photograph of the body in lateral view was prepared with the Automontage software (Synoptics Inc., Frederick, Maryland, USA) using a digital camera attached to a stereomicroscope. A digital camera attached to an optical microscope was used for photographing the ovipositor valvulae.

\section{TAXONOMY}

\section{Diestostemma Amyot \& Serville, 1843}

Diestostemma Amyot \& Serville, 1843: 572. Type-species: Cicada albipennis Fabricius, 1803: 62, by original designation and monotypy.

Remarks. Young (1968) included 32 species in Diestostemma and observed that this genus has a wide Neotropical distribution, occurring from Mexico to Paraguay and Bolivia. Among the proconiine genera, he considered Proconia Peletier \& Serville, 1825 the closest relative of Diestostemma because the two taxa share "the peculiar character of the scar at the apex of the head," 
as well as similarities in the venation of the forewings and in the structure of the aedeagus. The head scar is the place of insertion of a nymphal deciduous process (Young 1968). Diestostemma can be easily distinguished from Proconia, and from the remaining Proconiini genera, by the presence of a digitate process on the posterior margin of the lateral lobe of the pronotum (= proepimeron sensu Young 1968). In fact, this digitate process is apparently a synapomorphy of Diestostemma, defining it as a monophyletic taxon (G. Mejdalani, pers. obs.). Another remarkable feature usually observed in Diestostemma species is the presence of a copious hydrophobic coating of integumental brochosomes on the entire body except the head and the upper surface of the pronotum; the function of this conspicuous coating is still unclear, but it may provide protection against water and sticky substances, as well as against pathogens (fungi) (RAKITOv 2009). Diestostemma is a genus of complex taxonomy, having at least nine species of uncertain identity (see Young 1968). The phylogenetic position of Diestostemma within the Proconiini is still not clear. A preliminary morphological cladistic analysis, carried out by the senior author, suggested a sister group relationship between Diestostemma and Proconia, whereas the morphological and molecular analyses of Daniela Takiya (pers. comm.) yielded conflicting results. For instance, her morphological data indicated Proconia as the sister group of Diestostemma + Cicciana Metcalf, 1952, whereas combined molecular data (COI, COII, 16S, and histone H3) placed Diestostemma as the sister group of a clade formed by Paraulacizes Young, 1968, Aulacizes Amyot \& Serville, 1843, Pseudometopia Schmidt, 1928, and Proconosama Young, 1968.

\section{Diestostemma nasutum Schmidt, 1910}

\section{Figs 1-18}

Diestostemma nasutum Schmidt, 1910: 58. The female lectotype from Coca (Ecuador), housed in the Museum and Institute of Zoology (Polish Academy of Sciences, Warsaw) (Young \& NAST 1963, McKameY 2007), was photographed by WiLson et al. (2009). SснміDт (1910) had at hand one additional female (from Balzapamba, Ecuador), but males of D. nasutum were unknown to him.

Length, male $16.8 \mathrm{~mm}$, female $18.9 \mathrm{~mm}$.

Head (Figs 1-3), in dorsal view, strongly produced; median length (excluding nose-like projection) approximately 8/ 10 transocular width and greater than interocular width (the latter 8/10 to $9 / 10$ of median length); anterior margin not carinate, with short, median apical nose-like projection. Crown (Fig. 2), in dorsal view, with fovea on median portion between eyes; without longitudinal carina laterad of each ocellus; with pubescence on disc; without distinct M-shaped elevation bordering posterior margin; ocelli located on line between anterior angles of eyes, each ocellus distinctly closer to adjacent eye angle than to median line of crown; frontogenal sutures extending onto crown to near ocelli. Antennal ledges (Fig. 2) protuberant in dorsal aspect, anterior margin obliquely truncate; without longitudinal fovea; in lateral aspect (Fig. 3), digitiform, not carinate dorsally, anterior margin rounded. Face (Fig. 3) pubescent; frons flattened medially; epistomal suture obsolete; clypeus slightly protuberant, its contour continuing profile of frons.

Thorax (Figs 2 and 3) with pronotum distinctly broader than transocular distance; pronotal median length approximately equal to coronal median length; lateral margins convergent anteriorly; disc coarsely pitted on posterior two-thirds, with pubescence; posterior margin distinctly concave; dorsopleural carinae (Fig. 3) complete, approximately rectilinear and declivous anteriorly in lateral view; lateral lobes of pronotum (Fig. 3) with short, posteriorly directed digitate process at midlength of posterior margin. Mesonotum with scutellum slightly transversely striate. Forewings (Figs 1 and 4) opaque, without membrane; veins distinct and elevated; venation conspicuously reticulate, except on brachial cell, along most of costal margin, and on inner apical cell; wings of female, in rest position, entirely concealing ovipositor. Hindwings extending almost as far posteriorly as forewings; vein $\mathrm{R}_{2+3}$ incomplete. Hindlegs with femoral setal formula 2:0:0; first tarsomere shorter than combined length of second and third.

Color of crown brown with yellow antennal ledges. Pronotum brown with two maculae close to anterior margin, two maculae close to posterior margin, and markings on posterolateral margins, yellow. Mesonotum brownish-yellow. Forewings (Figs 1 and 4) yellowish-white (due to the presence of brochosomes) with mostly brown veins; basal portion with distinct dark brown spot adjacent to claval sulcus, $\mathrm{Cu}$ vein posterad of dark brown spot mostly yellow basad of first cross vein; basal portion also with brown macula adjacent to $\mathrm{R}+\mathrm{M}$ vein; basal half of corium with large brown area adjacent to claval sulcus; other smaller brown marks also present. Hindwings of milky-white aspect.

Male genitalia with pygofer (Fig. 5), in lateral view, not strongly produced; without processes; surface with numerous dispersed setae; ventral margin sinuous; posterior margin rounded inferiorly and truncate superiorly. Subgenital plates (Fig. 6), in ventral view, broad; separate throughout their length; apical half triangular with obtuse apex; surface with numerous dispersed setae. Connective (Fig. 7), in dorsal view, Y-shaped, linear, extending almost as far posteriorly as style apex; with median groove; with very long stalk and tiny, very slightly divergent arms. Styles (Fig. 7), in dorsal view, without distinct preapical lobe; apical portion broad, more sclerotized, distinctly curved inward; apex subtruncate, with two small, sclerotized dentiform projections on ventral surface and with small projection, directed posteriorly, on outer margin. Aedeagus (Fig. 8) symmetrical; shaft, in lateral view, with distal third distinctly curved dorsally; gonopore located on apex of shaft; atrium with conspicuous process on ventral margin, base of process with lobe directed anteriorly, process bifurcated on its basal portion (Fig. 9), rami long, 

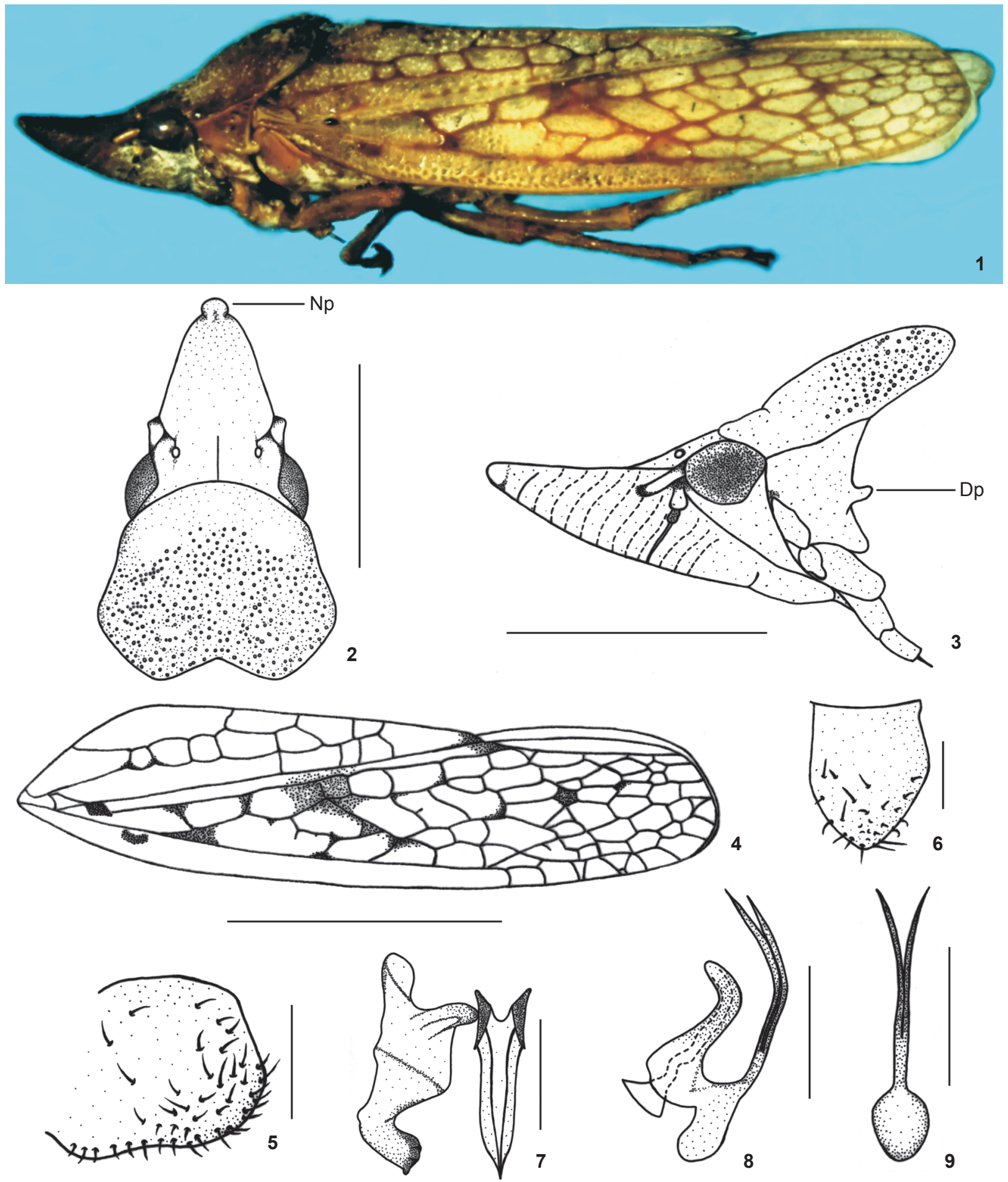

Figures 1-9. Diestostemma nasutum: (1) male, body in lateral view, length $16.8 \mathrm{~mm}$; (2) head and pronotum, dorsal view; (3) head and prothorax, lateral view; (4) forewing; (5-9) male genitalia: (5) pygofer, lateral view - basal portion damaged; (6) subgenital plate, ventral view; (7) style and connective, dorsal view; (8) aedeagus, lateral view; (9) basiventral aedeagal process, ventral view. (Dp) Digitate process, $(\mathrm{Np})$ nose-like process. Scale bars: $2-3=3.0 \mathrm{~mm}, 4=5.0 \mathrm{~mm}, 5-9=0.5 \mathrm{~mm}$. 


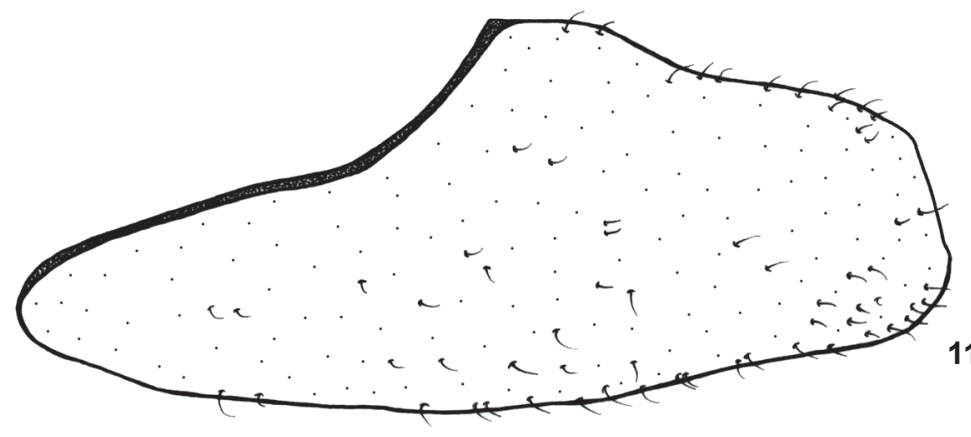

11
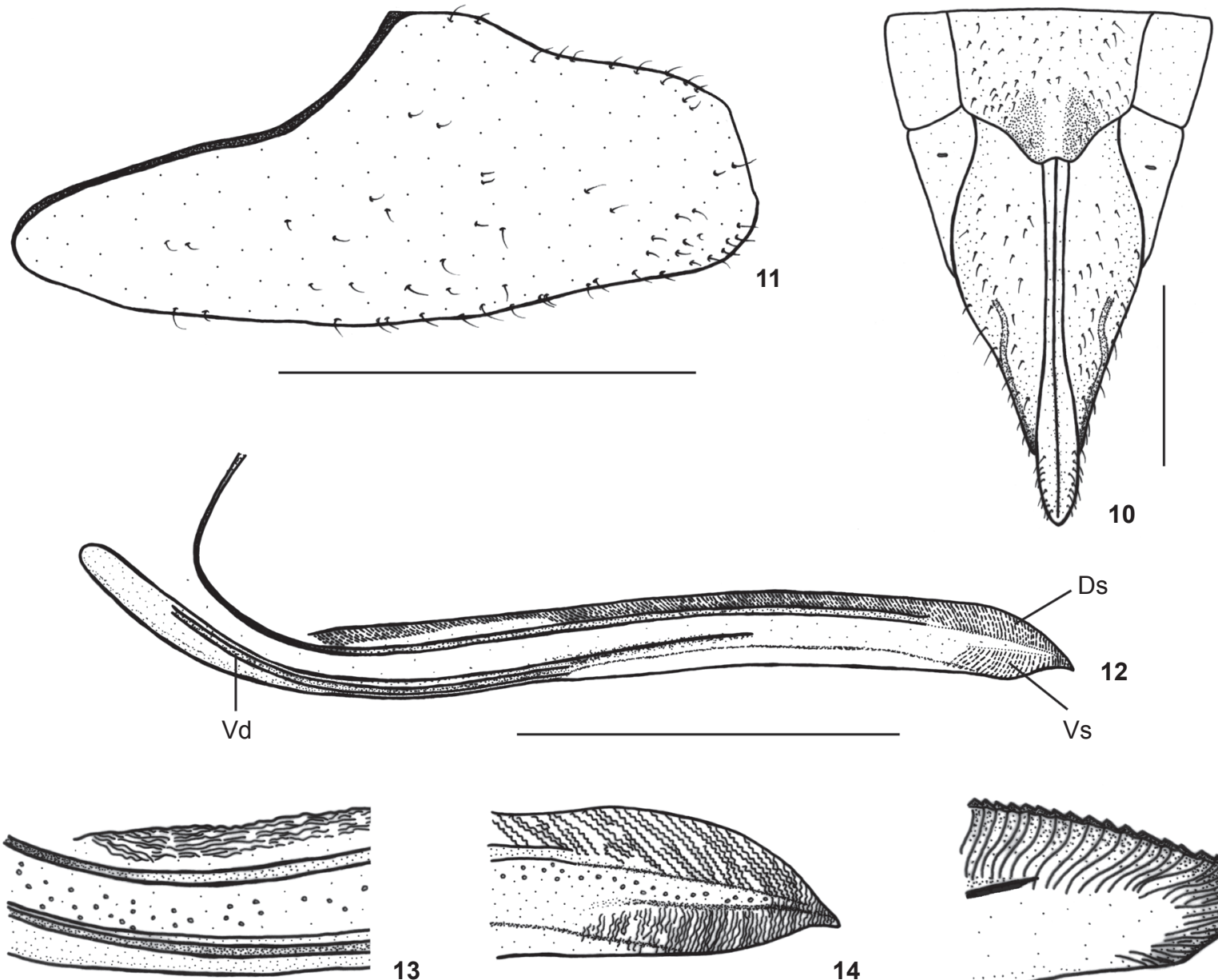

14

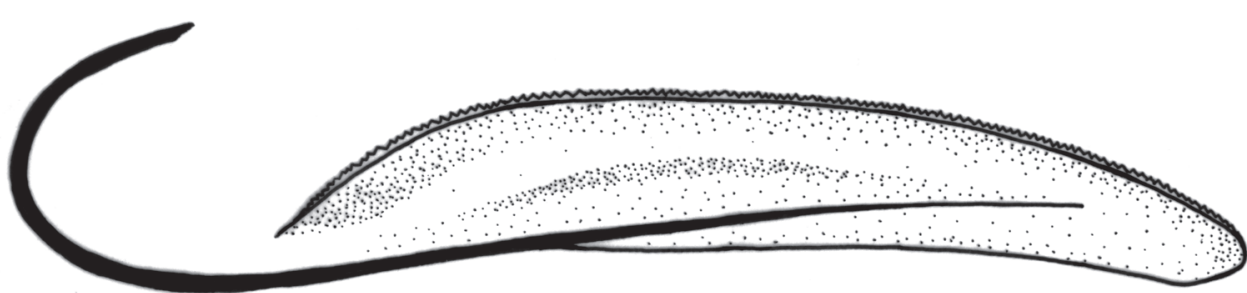

\section{5}

Figures 10-16. Diestostemma nasutum, female: (10) apical portion of abdomen, ventral view; (11-16) genitalia: (11) pygofer, lateral view; (12) first ovipositor valvula, general lateral view; (13) basal portion of first valvula, lateral view; (14) apical portion of first valvula, lateral view; (15) second ovipositor valvula, lateral view; (16) apical portion of second valvula, lateral view. (Ds) Dorsal sculptured area, $(\mathrm{Vd})$ ventral interlocking device, (Vs) ventral sculptured area. Scale bars: 10-12 and $15=2.0 \mathrm{~mm}, 13,14$ and $16=0.5 \mathrm{~mm}$.

curved dorsally, with acute apices, extending posteriorly farther than aedeagal apex; in ventral view (Fig. 9), base of process bulbous, rami distinctly divergent on apical portion.

Female genitalia with sternite VII (Fig. 10), in ventral view, with width of basal margin greater than anteroposterior median length; surface with short sparse setae and with two more heavily sclerotized areas on apical portion; posterior margin with broad median lobe, distal margin of lobe slightly concave. Internal sternite VIII without distinct sclerotized areas. Pygofer (Fig. 11), in lateral view, well produced posteriorly; with posterior margin mostly obliquely truncate; surface with sparse setae; in ventral view (Fig. 10), with pair of sinuous sclerotized 

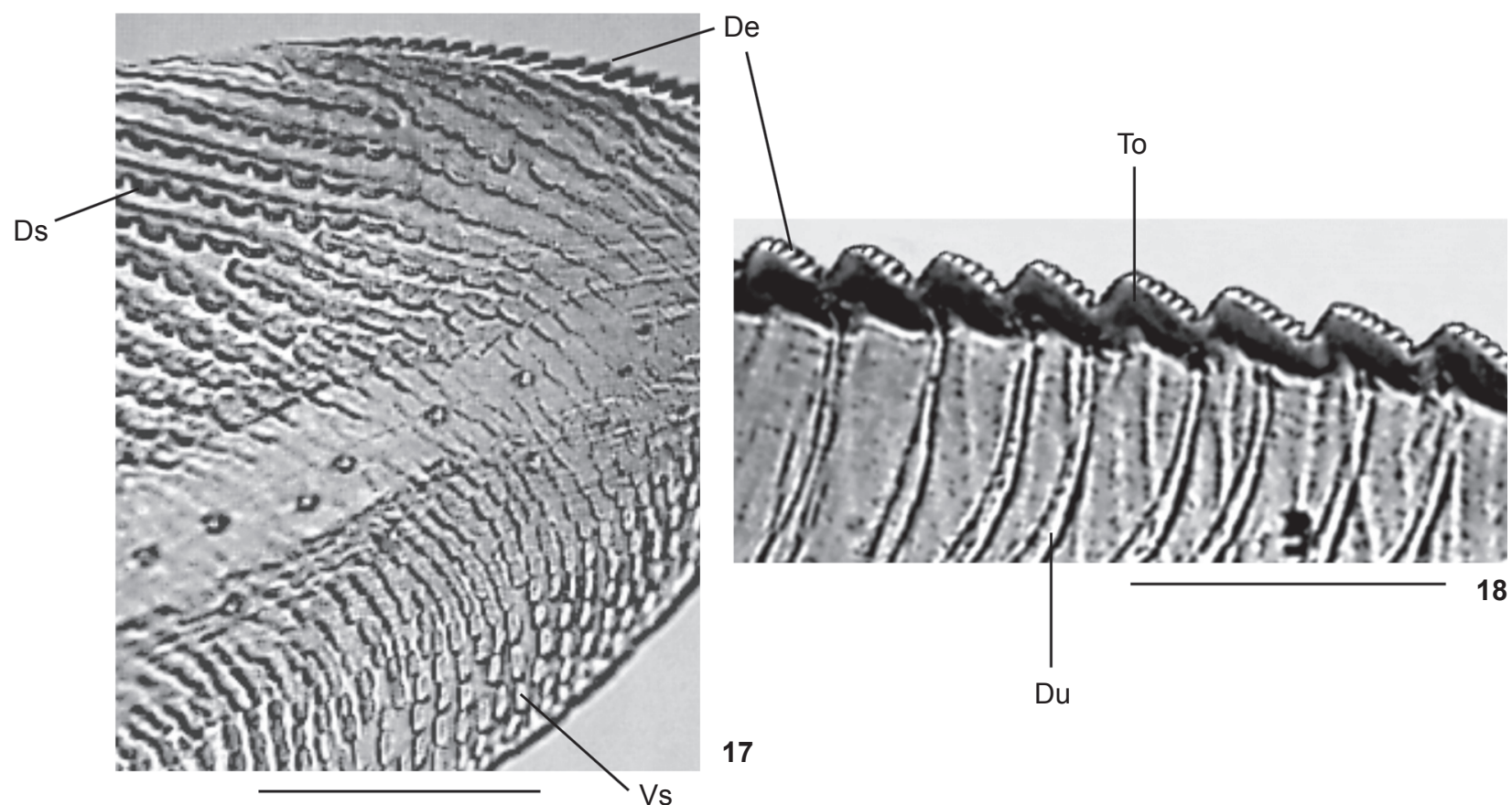

Figures 17-18. Diestostemma nasutum, female: (17) surface detail of the first ovipositor valvula near the apex, lateral view; (18) surface detail (superior portion) of the second ovipositor valvula at the apical third, lateral view. (De) Denticle, (Ds) dorsal sculptured area, (Du) duct, (To) tooth, (Vs) ventral sculptured area. Ds and Vs have scale-like processes. Scale bars: $0.1 \mathrm{~mm}$.

lines posteriorly. First valvifers, in lateral view, with anterior margin obliquely rectilinear, posterior margin broadly rounded. First ovipositor valvulae (Fig. 12), in lateral view, with apex acute; dorsal margin forming denticles on apical portion of blade (Fig. 17); dorsal sculptured area (Figs 12-14, 17) extending from basal curvature to apex, formed mostly by scale-like processes arranged in oblique lines, except basally with more linear processes arranged horizontally (Fig. 13); ventral sculptured area (Figs 12, 14, and 17) restricted to apical portion, formed mostly by scale-like processes; ventral interlocking device (Fig. 12) distinct on basal half of blade, its length corresponding to approximately one-half of blade length beyond basal curvature; base of first valvulae, in ventral view, simple, expanded laterally and, in dorsal view, with outer margin forming triangular projection directed inward. Second ovipositor valvulae (Fig. 15), in lateral view, regularly convex beyond basal curvature, without preapical prominence; apex (Fig. 16) subacute; about 105 teeth (Fig. 18), mostly triangular, distributed on dorsal expanded portion of blade; denticles (Fig. 18) on most teeth and on apical portion of blade; ducts (Fig. 18) extending toward teeth and toward apical blade portion. Gonoplacs, in lateral view, with basal half narrow and apical half distinctly expanded; apex rounded; apical half with ventral margin horizontal and dorsal margin descending gradually toward apex; setae distributed on apical portion and extending anteriorly along ventral margin of apical half.
Distribution. Ecuador (SCHмidt 1910, Young 1968) and Colombia (new record).

Material examined. Colombia. One male and one female, "S [San] Antonio \Columbia"; "1924"; "coll. A. JACOBI" (SMTD).

\section{DISCUSSION}

As stated above, our identification of D. nasutum was based on the fairly detailed original description (SснмiDT 1910) and on photographs of the female lectotype in dorsal and lateral views (WiLson et al. 2009). The key features occurring in combination for the recognition of this species, which are given in the original description and were observed in our specimens, are the nose-like process on the apex of the head (Fig. 2), the distinct, elevated brown forewing veins (Fig. 1), and the dark brown spot on the basal forewing portion adjacent to the claval sulcus with the cubital vein posterad of this spot mostly yellow anterad of the first cross vein (Fig. 1). It is important to emphasize that the present identification was not based on the dichotomous key of Young (1968) to the species of Diestostemma, because the latter author incorrectly identified some males as D. nasutum (G. Mejdalani, pers. obs. and D. Takiya, pers. comm.). In addition to being remarkably similar to the lectotype of $D$. nasutum, our specimens are quite distinct from other Diestostemma species (see WiLson et al. 2009). Only two species of Diestostemma were not photographed by 
WiLson et al. (2009), D. nervosum (Signoret, 1855) and D. brunneum Melichar, 1924. We have studied the original descriptions of these two species (Signoret 1855, Melichar 1924) and they do not correspond to our specimens.

The aedeagus of D. nasutum has a conspicuous basal process whose rami extend farther posteriorly than the aedeagal apex (Fig. 8). This feature is also observed in D. rufocirculum Schmidt, 1910, D. rizopatroni Young, 1968, D. stesilea Distant, 1908, D. ptolyca Distant, 1908, D. colombiae Young, 1968, D. blantoni Young, 1968, and D. schmidti Melichar, 1924 (Young 1968). The aedeagus of $D$. nasutum can be distinguished from those of the preceding species by the following features (Figs 8 and 9): (1) shaft with the distal third distinctly curved dorsally; (2) base of basiventral aedeagal process with a lobe directed anteriorly; and (3) basiventral aedeagal process bifurcated on its basal portion. Furthermore, the style of D. nasutum (Fig. 7), whose apical portion is broad, distinctly curved inward, and with the apex subtruncate, is quite distinctive. This style is similar to that of $D$. rizopatroni, but the latter does not extend almost as far posteriorly as the connective apex (Young 1968), as it does in D. nasutum.

Mejdalani (1998), in a comparative study of the female genitalia in the Cicadellinae stricto sensu (Cicadellini and Proconiini), included Proconiini representatives of Tretogonia Melichar, 1924, Homoscarta Melichar, 1924, Ciccus Latreille, 1829, Ichthyobelus Melichar, 1925, and Raphirhinus Laporte, 1832. Comparisons of the Diestostemma ovipositor with those of these five genera called attention to characteristics of potential taxonomic value in both the first and second valvulae. The general form of the blade of the first and second valvulae varies among these six genera. For instance, the second valvulae in Homoscarta are distinctly expanded after the basal curvature and then the dorsal margin forms a rectilinear declivity toward the apex, whereas in Diestostemma they are regularly convex beyond the basal curvature. In the blade form, the second valvulae of Diestostemma are more similar to those of Ichthyobelus, but the latter have a preapical prominence that is not present in the former. The form of the second valvula teeth is also variable; they can be, for instance, quadrangular (as in Raphirhinus) or triangular (as in Diestostemma). The teeth may be distinctly covered by denticles (as in Diestostemma) or mostly without denticles (as in Ichthyobelus). In the first valvulae, in addition to the distinct blade forms, variations are observed in the size of the ventral interlocking device and in the processes of the dorsal and ventral sculptured areas. The ventral interlocking device, for instance, is much shorter in Tretogonia (approximately one-third of blade length beyond basal curvature) than in Diestostemma (approximately one-half of blade length beyond basal curvature); in the former genus, this device extends only slightly beyond the basal curvature of the valvula, whereas in the latter it extends well beyond the basal curvature. The processes of the dorsal sculptured area may be linear (as in Homoscarta) or scale-like (as in Diestostemma). Finally, the internal sternite VIII, located at the base of the ovipositor, may be membranous (as in Diestostemma) or it may bear distinct sclerites (as in Tretogonia). The female genitalia of members of the Cicadellini have been studied in far greater detail than in the Proconiini. Our results confirm the perception that the female genitalia of the Proconiini can be a source of a large number of useful taxonomic characters.

\section{ACKNOWLEDGMENTS}

The loan of specimens used in this study was kindly arranged by Rainer Emmrich (SMTD, retired). The manuscript benefited from the useful comments of Rachel Carvalho and Luiz G. Rodrigues (Museu Nacional, Rio de Janeiro), Márcio Felix (Fundação Oswaldo Cruz, Rio de Janeiro), and Daniela Takiya (Universidade Federal do Rio de Janeiro). The photograph of the body in lateral view was taken by Rachel Carvalho. This study was in part supported by the Fundação de Amparo à Pesquisa do Estado do Rio de Janeiro - FAPERJ (grant number E-26/171.281/2006).

\section{LITERATURE CITED}

Амyot, C.J.B. \& J.G. Serville. 1843. Histoire naturelle des insectes. Hémiptères. Paris, Librairie Encyclopédique de Roret, LXXVI+675p.

Ceotto, P.C.; G. Mejdalani \& M. Felix. 2000. Notes on Neotropical Proconiini (Hemiptera, Cicadellidae, Cicadellinae), II: description of the female of Anacrocampsa wagneri Young, 1968. Boletim do Museu Nacional (Zoologia) 435: 1-8.

Hamilton, K.G.A. 1981. Morphology and evolution of the rhynchotan head (Insecta: Hemiptera, Homoptera). Canadian Entomologist 113: 953-974.

HILL, B.G. 1970. Comparative morphological study of selected higher categories of leafhoppers (Homoptera: Cicadellidae). Ann Arbor, University Microfilms, XI+187p.

McKamey, S.H. 2007. Taxonomic catalogue of the leafhoppers (Membracoidea). Part 1. Cicadellinae. Memoirs of the American Entomological Institute 78: 1-394.

Mejdalani, G. 1998. Morfologia externa dos Cicadellinae (Homoptera, Cicadellidae): comparação entre Versigonalia ruficauda (Walker) (Cicadellini) e Tretogonia cribrata Melichar (Proconiini), com notas sobre outras espécies e análise da terminologia. Revista Brasileira de Zoologia 15: 451-544.

Mejdalani, G. 2006. Notes on Neotropical Proconiini (Hemiptera: Cicadellidae: Cicadellinae), III: redescription of the Amazonian sharpshooter Ichthyobelus youngi Kramer. Deutsche Entomologische Zeitschrift 53: 108-113.

Mejdalani, G. \& R. Emmrich. 1998. Notes on Neotropical Proconiini: new species of Acrobelus Stål and Dichrophleps Stål and the male of Proconosama haenschi (Melichar) (Insecta: Auchenorrhyncha: Cicadellidae: Cicadellinae). Entomologische Abhandlungen des Staatlichen Museums für Tierkunde Dresden 58: 131140. 
Mejdalani, G.; D.M. Takiya \& R.A. Carvalho. 2006. Notes on Neotropical Proconiini (Hemiptera: Cicadellidae: Cicadellinae), IV: lectotype designations of Aulacizes Amyot \& AudinetServille species described by Germar and revalidation of $A$. erythrocephala (Germar, 1821). Arthropod Systematics and Phylogeny 64: 105-111.

Mejdalani, G.; L.A.A. Costa \& R.A. Carvalho. 2008. Two new species of Zyzzogeton Breddin and the female of $Z$. haenschi Breddin (Hemiptera: Cicadellidae: Cicadellinae: Proconiini). Journal of Natural History 42: 1639-1648.

Mejdalani, G.; A. Carpi \& R.A. Carvalho. 2009. Notes on Neotropical Proconiini (Hemiptera: Cicadellidae: Cicadellinae). VI: description of the male of Deselvana falleni from the Atlantic rainforest of southeastern Brazil. Zoologia 26: 769-773.

Melichar, L. 1924. Monographie der Cicadellinen. Annales Historico-Naturales Musei Nationalis Hungarici 21: 195243.

Nielson, M.W. 1965. A revision of the genus Cuerna (Homoptera, Cicadellidae). Technical Bulletin of the United States Department of Agriculture 1318: 1-48.
RAKITOV, R.A. 2009. Brochosomal coatings of the integument of leafhoppers (Hemiptera, Cicadellidae), p. 113-137. In: S.N. Gorв (Ed.). Functional surfaces in biology: little structures with big effects. Dordrecht, Springer, vol. 1, XVIII+384p.

Schмid, E. 1910. Genus Diestostemma Am. et Serv., ein Beitrag zur Kenntnis der Jassiden. (Hemiptera - Homoptera.). Stettiner Entomologische Zeitung 71: 30-62.

Signoret, V. 1855. Revue iconographique des Tettigonides. Annales de la Société Entomologique de France 3: 507-528.

Wilson, M.R.; J.A. TuRner \& S.H. McKamey. 2009. Sharpshooter leafhoppers of the world (Hemiptera: Cicadellidae subfamily Cicadellinae). Available online at http://naturalhistory. museumwales.ac.uk/sharpshooters/home.php [Accessed: 19/V/2010].

Young, D.A. 1968. Taxonomic study of the Cicadellinae (Homoptera: Cicadellidae), Part 1, Proconiini. Bulletin of the United States National Museum 261: 1-287.

Young, D.A. \& J. NAst. 1963. Cicadelline types of species described by Edmund Schmidt (Homoptera, Cicadellidae). Annales Zoologici 21: 265-271.

Submitted: 12.VII.2010; Accepted: 23.IX.2010.

Editorial responsibility: Walter A.P. Boeger 